\title{
Hydronymy and its geographical relevance in historical Moldavia ${ }^{\dagger}$
}

\author{
Ionel Muntele* \\ Faculty of Geography and Geology, "Alexandru Ioan Cuza" University, Bd. Carol I 11, 700506 Iași, Romania \\ Institute of Geography, Iași Branch of the Romanian Academy, Bd. Carol I 8, 700505 Iași, Romania
}

\section{Article info}

History:

Received June 18, 2018

Accepted July 5, 2018

Published October 7, 2018

Keywords:

toponymy

linguistic contact

semasiology

\begin{abstract}
Emerged from the preoccupations to research the process of population evolution in historical Moldavia, the present study proposes an analysis of the spatial distribution and geographic relevance of the hydronyms in this region. For this purpose, 2040 watercourses, identified in various cartographic sources, were inventoried. They were given additional information on the origin of their names and meanings. The paper uses the etymological explanations taken from the consulted bibliography and the categories of geographical relevance related to the elements of the natural or anthropic framework. Beyond the limits imposed by the inherent documentary gaps or controversies in explaining the etymology and the meaning of some names, the results obtained by analysing the statistical distribution of the retained categories represented the support of some typological classifications at the level of the 32 main hydrographic basins. The conclusions drawn show the existence of strong connections with the spread of some (present or past) ethnic groups, as well as with the features of the natural environment or induced by specific socio-economic relations.
\end{abstract}

\section{Introduction}

The study of hydronyms can be extremely useful in the analysis of the process of population evolution of a territory. Clues on the stratification of the denominations given by the communities that succeed each other within a certain space and the context that produces certain meanings, often correlated with elements of the natural and social environment, can support the development of working hypotheses or validate conclusions resulting from the investigation of various bibliographic sources. The present study took into account only the hydronyms related to water courses (potamonymes), thus restricting the meaning of Lebel's classical definition of hydronyms (1956, p. 1) ${ }^{1}$. As regards "minor hydronomy", a terminological syntagm often referred to in the text, it does not entirely coincide with microhydronymy, which also covers elements of small size (such as wells, springs, etc., see Urazmetova \& Șamsutdinova, 2017, p. 28).

Developed at the European level in the extensive work of such authors as Топоров \& Трубачев (1962), dealing with the eastern Baltic Sea regions or Krahe (1964), the study of hydronyms generated controversy over the origin of the names of the most important watercourses in Europe, considered to derive from an ancient Pre-Indo-European, Vasconic or Semitic layer in Western Europe according to Vennemann (2003). Current analytical means based on mathematical methods (such as the logarithmic calculation) using Swadesh lists have led to bold conclusions such as those provided by Peust (2015, p. 214), according to whom $87 \%$ of the European rivers longer than $250 \mathrm{~km}$ have names that are at least 2000 years old, and $25 \%$ even surpass 20000 years. This author also included in his analysis hydronyms within the Romanian area, for some of them also using information provided by Romanian authors. This is the case of the Siret

\footnotetext{
†This paper was presented at the symposium “Toponymy between history, geography and linguistics”, Iași, May $10^{\text {th }}, 2018$.

*Email address: imuntele@yahoo.fr.

${ }^{1}$ The quoted author considered that hydronyms should include not only the names given to watercourses, lakes or marshes, but also their constituent elements, such as confluences, waterfalls, vents, spillways, when they have distinct names.
} 
Ionel Muntele

river, first mentioned by a $10^{\text {th }}$ century Byzantine source as Sarat, which Brezianu (2002, p. 146) explains in Romanian as "salty".

The hydronyms within the Romanian space have enjoyed special attention, both in specific studies and in more complex works. The study of hydronyms has generally been directed toward deciphering the meaning of major hydronyms, largely inherited from the substrate. Geographically dispersed, they represent an interesting topic for comparative studies. From a geographic point of view, however, minor hydronymy proves to be much more interesting, often resulting from a more recent stratification, relatively easy to explain through its correspondence with current languages.

Starting from these considerations, for this paper we have chosen historical Moldavia as a reference area, considering its limits before its successive division $(1774,1812)^{2}$. The size of the territory (about $94000 \mathrm{~km}^{2}$ ) may involve major differences in the distribution of hydronyms, but the unitary historical evolution, at least before 1774, allows the hypothesis of the existence of high-frequency names, often in line with the features of the natural environment. The option for this vast space was also facilitated by the possibilities of computerized processing of the analysed elements. While the scientific literature comprises several studies on hydrographic basins in the region (Ciubotaru, 2001; Cojocaru, 2005; Butnaru, 2011; Eremia, 2012 and 2017; etc.) or on certain categories of hydronyms (Moldovanu, 1987 and 2007-2008; Raevschi, 2006; Eremia, 2014; etc.), there is no wide-scale approach, at the level of the whole region, even from a more general (geographical) perspective. On an even larger scale, efforts in this regard are significant; it is worth mentioning Felecan \& Felecan's study (2015) on the etymological layers reflected in the Romanian hydronymy.

In this context, the main objective of our study is to highlight the spatial distribution of some categories of hydronyms in relation to their origin and significance from the perspective of the natural or human-geographic framework (Ungureanu \& Boamfă, 2006, p. 29). They are primarily concerned with the morphology of the valleys, the physic-chemical characteristics of water, the ecosystem characteristics, the ways of economic capitalization of local resources or land planning. For this purpose, the paper made use of the etymological explanations extracted from the scientific literature, for the (many) controversial cases accepting broad consensus variants.

\section{Materials and methods}

In order to track the geographical relevance of the hydronyms in the area of historical Moldavia, a comprehensive database of 2040 watercourses was first created. Their identification was mediated by the maps provided by the Military Topographic Directorate (at 1:50 000 scale, Top Map), by the State Cartographical and Geodetic Fund of the Republic of Moldova (at 1:50000 scale, FNDG) and the Soviet military topographic funds (HARTA URSS), available at 1:100 000 scale, for territories currently belonging to Ukraine. The collected information has been confronted with those extracted from older cartographic sources, including to establish the correctness of some names or because they are omitted in current sources: ATLAS MOLD., the collection of maps of Bukovina reedited in 2013 in Suceava under the coordination of I. Iosep (HARTA BUC.), etc. For the same purpose, MDG, GONT,A, MDTM, the geographic dictionaries of Bessarabia (ARBORE) and Bukovina (GRIGOROVITZA), and the Ukrainian Dictionary of Hydronyms (HIDR. UCR.) were also consulted.

The indicated number covers all water courses with a length of more than $5 \mathrm{~km}$ in the mountain areas, $7 \mathrm{~km}$ in the hilly areas, and $10 \mathrm{~km}$ in the plain areas. The reason for this discrimination is related to the density of the hydrographic network, which is superior in the mountain area. The information was organized on hydrographic basins, going up to tributaries of rank IV or V, the sample being as representative as possible. Although shorter water courses are frequently found on cartographic materials, especially in the Carpathian area, they have not been taken into account; instead, numerous valleys with seasonal or

\footnotetext{
${ }^{2}$ Including the Budjak and the upper basins of the tributaries of some Carpathian rivers, for reasons of spatial continuity of some hydrographic basins.
} 
intermittent discharge from the lower areas were introduced into the database, since some of them have considerable size.

The primary database included, besides the hydrographic network, the length expressed in kilometres. The cartographic support needed to represent the results was extracted from the compilation of topographic maps in Adobe Illustrator. The database has as its main reference the Danube, for its first order tributaries (Siret, Prut, etc.), respectively the Dniester and the direct tributaries of the Black Sea (through fluvial and maritime lagoons). Two series of information were added to this primary database:

a. information on the origin of hydronyms, separating several categories, each hydronym receiving an appropriate indication;

b. information on their significance, according to the etymological explanation taken from bibliographic sources, assigning another appropriate indicative to each hydronym.

The processing of information required first the calculation of the weight of each category of hydronyms, on hydrographical basins (delimited so as to result in areas with a comparative size) and on major physical geographic regions (mountain and piedmont, plateau, plain). The weights were mapped for each category of hydronyms, thus drawing preliminary conclusions on the their distribution, spatial extension or grouping in distinct areas.

The information thus processed provided the support of further analyses on hydrographic basins, applying one of the current methods of typological classification of both series of information: on origin and geographic significance respectively. The option for hierarchical clustering (AHC) in the XLSTAT program is justified by the use as a discriminating factor of the disparity expressed by the Euclidean distance, namely the differences between the retained statistical units (river basins in our case). This generates groupings according to the similarities of the distribution profile of the analysed categories, based on the minimum variance criterion (Hastie et al., 2009, p. 520). The mapping of the results allowed us to obtain a synthetic image on the analysed topic.

\section{Results and discussions}

\subsection{Distribution and typology of hydronyms by origin}

For the primary processing of information on the origin of the hydronyms, 7 categories were used: a) hydronyms of unknown or uncertain origin (EN); b) Romanian hydronyms derived from words of Latin origin (R); c) Romanian hydronyms derived from words of other origin (excluding Slavic, RD); d) Romanian hydronyms derived from words of Slavic origin (RSL); e) Slavic hydronyms (SL); f) Turanian (Turkic) hydronyms (TUR); g) Hungarian hydronyms (MG).

The spatial distribution of these categories highlights the predominance of the Romanian hydronyms but also the significant weight of the hydronyms of Slavic, Turanian or Hungarian origin. The location of the latter corresponds to some areas of long-lasting interaction between the Romanian population and Slavic, Turkic or Hungarian communities: the Slavic hydronyms ( $9.8 \%$ of the total) are predominant in the northwestern part of the region (the Upper Prut basin, upstream of Chernivtsi), their incidence decreasing to the southeast, in the Budjak Plain being virtually absent ${ }^{3}$; Turkic hydronyms ( $8 \%$ of the total) have a reverse distribution, predominantly in the southeast and with an isolated presence in the rest of the territory, with a cluter tendency in the lower regions (Middle Prut Plain) ${ }^{4}$; hydronyms of Hungarian

\footnotetext{
${ }^{3}$ If most of the hydronyms considered to be of Slavic origin are unquestionable, there are also some that stir up discussion. It is the case, for example, of Năruja-Nereju couple of Vrancea area, sometimes derived from the Hungarian nyir' birch'. Топоров \& Трубачев (1962, p. 198) mention a river named Naružas in Latvia, another called Narussa in Eastern Prussia, and a tributary of Desna, Nerussa, also called Neruza. The Slavic origin seems safer even in the hypothesis of the Baltic origin, possible in the context of Slavic migration.

${ }^{4}$ The capacity of Turkic populations to fix toponyms was strong even in cases where their domination was temporary. For example, in the northern county of Hotin, transformed into an Ottoman territory (1712-1812), a tributary of the Larga stream that flows into Prut in the proximity of Lipcani is called Calangiu, derived from the Turkic kalayci, a term referring to the Gypsy tinsmiths.
} 
origin (3.1\% of the total) are primarily encountered in the Trotuș and Bistrița basins, covering almost the entire Carpathian region, extending eastwards of the Siret valley.

The distribution of Romanian hydronyms derived from inherited Latin words (30.7\% of total) is also significant, their maximum frequency being found in the central-southern part of the region (from the lower Siret basin to the Botna basin). In the northwest, along the Dniester River and in the southeastern extremity of Budjak, their frequency is much lower, without being insignificant ${ }^{5}$, however. Their resistance in the areas with a reduced Romanian presence today proves the long-lasting cohabitation process, contradicting the opinions of some Ukrainian scholars who argue that Romanian hydronyms in the Dniester basin are late (only from the $18^{\text {th }}$ century), minimizing their importance. For example, the over 150 Romanian hydronyms identified and recognized as such in the Ukrainian part of the Dniester basin are considered "insignificant" (Вербич, 2015). Different opinions, argued documentarily, are supported by other scholars who, at least for Bukovina, attest to a massive change of toponymy during the AustroHungarian occupation, including the translation or adaptation of some Romanian names in Ukrainian (Prisacaru, 2013).

The expansion of the Romanian population to the east of the Carpathians seems to have also had a strong direction from the south to the north, and not only from the Carpathian area to the Dniester, as is commonly accepted. There is a surprising over-average frequency of the Romanian hydronyms in the Central-Western Budjak (the basins of Cogîlnic and Ialpuh, where even the large tributaries of these rivers with ancient names of Turkic origin bear Romanian names, early attested: Galbena, Schinoasa, Saca, respectively, Lunga with its affluent Lunguța, Salcia Mare, etc.).

A very large weight is held by the Romanian hydronyms derived from words borrowed from other languages or inherited from the substrate, relatively evenly distributed ( $43.2 \%$ in total, most of them Slavic loans, namely 23.6\%). There is a close correlation between the frequency of the Slavic hydronyms and the Romanian hydronyms of Slavic origin, with a higher incidence in the north-eastern half of the region (Bukovina, northern Bessarabia). We can speak of the occurrence of a permanent Slavic influence in these areas, unlike the rest of the region, where it is much older. Romanian hydronyms derived from words other than of Slavic origin are more frequent in the middle basins of the Siret, Prut and Dniester, practically separating the area with powerful Slavic influence in the northwest from that with Turkic influences in the south-east.

A special situation is represented by the 106 hydronyms of controversial or unknown origin $(5.2 \%$ of the total), unevenly distributed, with a high frequency along the Dniester (up to 20\% in the upstream sector of the confluence with the Naslavcha brook). Most of them are unique, but some refer to water courses, as is the case of Molnița (tributary of the Siret or Prut) ${ }^{6}$, Burla (tributary of Sitna or affluent of the Iaslovăt brook, itself tributary of Solca in the Suceava basin), Stemnic/Stebnic (tributary of Bîrlad, respectively of Siret on its upper course), Buhalnița (tributary of Bistrița, respectively of Bahlui), etc. There are also hydronyms that derive from a common theme such as the Drislea/Dresleuca/Drislavăt series $^{7}$. Some of these hydronyms have interesting names from an etymological perspective; it is the case of Dona, for instance, a left tributary of the Prut River at Drepcăuți $(14 \mathrm{~km}$ long, Briceni district,

\footnotetext{
${ }^{5}$ With notable presence, however, like the Sărata river in the eastern Budjak, or numerous streams tributary to the Dniester in the county of Hotin (Chetrosul, Puțita, Țarălungă, Surda, Secureanca, etc.), whose names have been preserved despite the change of the ethnic structure in the last centuries. In some cases, the local, Romanian name was kept only in the upper course, for example Alcalia, in the east of Budjak, is called Răpciuga (Glanders) in the springs area, including in older documents.

${ }^{6}$ Unconvincingly explained by Raevschi (2006, p. 102) by the Lithuanian molis 'mud' and considered to have derived from the substrate. The same theme, moln-, can also be found in the name of a tributary of the Middle Ciuluc, Molnic, in the lower basin of Răut. In the Dnieper Basin, Топоров \& Трубачев (1962, p. 196) mention many hydronyms on the same theme: Moline, Molina, Molupis, Molingiris.

${ }^{7}$ Raevschi (2006, p. 105) compares them with the Latvian Driksne or the Prussian Driksna; a left tributary of Desna, documented by HIDr. UCR. (p. 183) is called Drişleva. At the beginning of the Middle Ages, the area was populated by Baltic tribes.
} 
Republic of Moldova $)^{8}$. Many of these have "odd" names in the local context, being perhaps able to be elucidated by linguistic expertise. Thus, along the Dniester, in the former Hotin and Soroca counties, we can mention: Midotiul ( $9 \mathrm{~km}$ long, tributary of Miusca at Rașcov); Surșa, with its tributary Șost (21 $\mathrm{km}$ and $10 \mathrm{~km}$ long, respectively, which meet Dniester at Nahoreni, Chelmenți district); Șeinu (12 km long, tributary at Molodova, Secureni district); Burbonea (10 km long, tributary at Vetreanca, Secureni district), Ojov (7 km long, tributary at the homonymous locality, north of Secureni), Voromid ( $9 \mathrm{~km}$ long, tributary at Iorjnița, Soroca district); Voșcasac and its tributary Văcăsar (15 and 9 km long, respectively, tributary at Sănătăuca), etc. ${ }^{9}$ Such names can also be encountered in the rest of Moldavia, but they are more dispersed. We can mention: Argiu, a small tributary on the upper course of Siret, Carecna $(27 \mathrm{~km}$ long, right tributary of Siret at Pufești, Vrancea County), Cuțigna (19 km long, also called Rediu, right tributary of the Vaslui river) in the Siret basin; Tata $(14 \mathrm{~km}$ long, tributary of the Lopatnic in Briceni district, Republic of Moldova), Aluza ( $15 \mathrm{~km}$ long, right tributary of Jijia in Iacobeni, Iași county) in the Prut basin; T,aul ( $9 \mathrm{~km}$ long, right tributary of Cubolta at the village with the same name), Segala (31 km long, tributary of Răut at Sărătenii Vechi, Telenești district), Motța $(27$ km long, tributary of Răut at Brănești), Alvnagar (11 km long, tributary of Molovateț at Ghermănești, Telenești county), in the Răut basin; Arpintea ( $8 \mathrm{~km}$ long, tributary of the Știubei brook in the Lower Dniester Basin ${ }^{10}$ ), etc.

If we group the Romanian hydronyms derived from words of Latin origin and those derived from words borrowed from other languages or inherited from the substrate, we obtain a share of $73.9 \%$, sufficiently consistent to consider that the dominant hydronymic fund is Romanian, in agreement with other specialists (Eremia, 2012, p. 73). Even in the northwest, an area currently populated predominantly by ethnic Ukrainians, they reach values of $43.8-55 \%$, while in the extreme southeast, which still retains the strong footprint of Turkic nomads, the share reaches $29.2-37.7 \%$. In the rest of the region, the values are close to the average, with a maximum recorded in the Middle Siret valley (between the confluence of Suceava and Bistrița, including the Șomuzul Mare basin, 91.2\%), perhaps not by chance, if we think that the old medieval capital Baia is in the neighbourhood.

The typological classification according to the presented methodology suggests the existence of six distinct areas from the perspective of the combination of hydronyms by origin (Fig. 1). To make it easier to understand how the types are differentiated, the figure includes the dendrogram (cluster) and the graphic profile of the types, expressed in percentage units. It should also be specified that the typology focused on the spread of the categories identified within each river basin in relation to the others, and not to their predominance within the same basin.

A first type covers the central-southern part of historical Moldavia, extending along the Prut River to the Lower Danube. It is the area with the largest share of Romanian hydronyms (including those derived from loans). It is surrounded by type 2, a larger area covering the middle part of the region (the Siret-Prut interfluves, with extensions to the basins of Moldova, Suceava and the Middle Prut), where the weight of the Slavic hydronyms is significantly more important. Laterally, two other areas belonging to types 3 and 4 are distinguished, whose structure, similar to the types 1 and 2 , is characterized by a significant share of hydronyms of Hungarian (type 3, located in the Carpathian and Subcarpathian areas) and Turkic origin (type 4, extended in the north-central part of Bessarabia), respectively.

Type 5 groups a strip in the shape of an arc of a circle, from the Ceremuș to the Middle Dniester

\footnotetext{
${ }^{8}$ We refer to the possibility of its deriving from the Iranian root don, designating a watercourse in the language of the Ossetians in the Caucasus, descendants of the Alans.

${ }^{9}$ Some of these seem to have been borrowed in a deformed shape, since there cannot be found equivalents in the hydronymy of the larger eastern European space. The shape of some of them seems to be Slavic, as for example Ojov, attested early but with uncertain etymology as Ojogov (GONȚA, p. 179), but it can also be close to hydronyms like Ajovka, Ajevka, from the upper Dnieper, explained by Топоров \& Трубачев (1962, p. 175) through the Lithuanian $o z$ ż or the Latvian ažis 'goat'. Șost could be compared to a tributary of Desna, Shostka, which is suppoed to derive from mecm 'lily' in the north-eastern Ukrainian dialects.

${ }^{10}$ This hydronym could be linked to the Hungarian árpa or the Turkic arpa, both having the same meaning: 'barley'. If we take into account that this small watercourse is in the neighborhood of Ciobîrciu (Ștefan Vodă district), where Bandini mentioned a Catholic community of 200 people in 1646, the first variant seems to be reliable.
} 


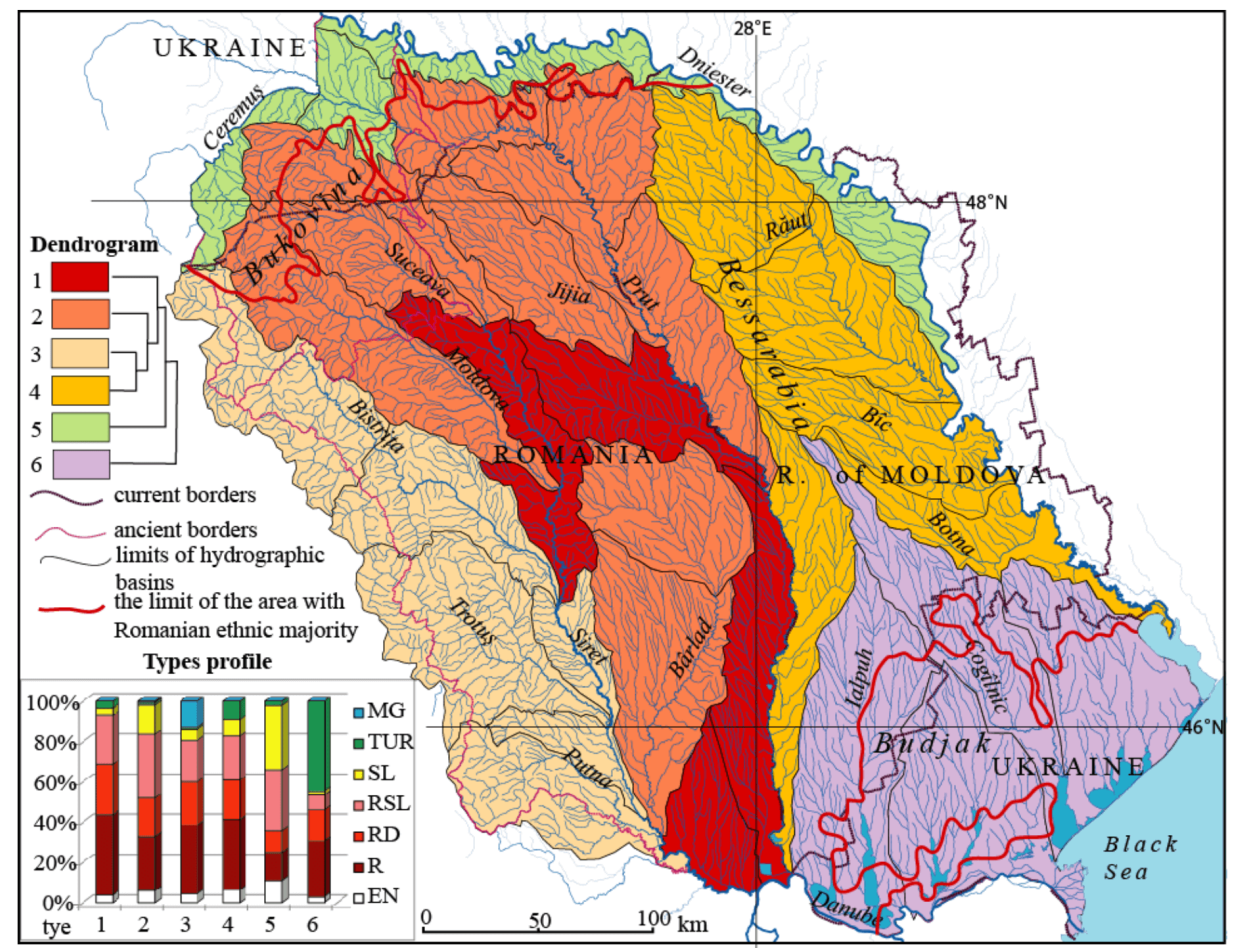

Figure 1: The typology of hydronyms in historical Moldavia by origin

river upstream of the confluence with Răut, where the weight of the Slavic hydronyms is very important, including in the form derived in or adapted to Romanian. Another peculiarity, already mentioned, is the frequent presence of some hydronyms of unclear origin. If in the northwest the predominant presence of the Ukrainian population justifies this situation, along the middle valley of the Dniester, on the present territory of the Republic of Moldova, this structure can be attributed to a massive slave presence in the past. According to the opinion of some scholars, the Slav tribe of the Tiverts mentioned in the medieval Russian chronicles (Spinei, 1999, p. 113) settled down between Răut and Dniester rivers. Massive Slavic influence in hydronymy seems to have come from several directions: the most important, from the northwest, descending to the valleys of the Prut, Siret and their tributaries; from northeast, broadcast along the middle Dniester and its Bessarabian tributaries; from south to northeast, especially along the Bîrlad, in the basin of which it is possible to interfere with the other two, thus generating a higher than average frequency of hydronyms of Slavic origin ${ }^{11}$.

The last type, 6 , is very clearly personalized by an almost perfectly balanced combination of Turkic and Romanian hydronyms. The poor presence of Slavic hydronyms (most adapted to Romanian) can be attributed to the use of the Budjak region as the basis for the expansion of nomadic populations or as a transit area. Surprisingly, however, there is a massive and sustainable presence of Romanian hydronyms (including in the case of some channels linking the Danube to the lakes of southern Bessarabia) ${ }^{12}$. At first sight it could be said that the Romanian population probably created the first sustainable system of settlements, especially in the hilly area along the Prut (the hills of Tigheci, the seat of one of the "republics" mentioned by Dimitrie Cantemir) or along the Dniester ("Khan" villages, between the Botna and Dniester rivers), or on the terraces of the lakes along the Danube. In this way, the populations colonized by the

\footnotetext{
${ }^{11}$ There are many correspondences between the names of the tributaries of Bîrlad, and some hydrographic basins in Ukraine, both in the west (Stavnik, Stebnik in the Upper Dniester basin) and in northeast (Jiroveț/Jeraveț, Sacovița int the Middle Dnieper basin) or east (Luhan, tributary of Donets). At the same time, some tributaries seem to betray a southern Slavic origin (Gîrbovăț, Bîrzota, etc.).

${ }^{12}$ For example, Lata, linking the Danube to Lake Cahul, Repedea Mare and Repedea Mică, linking the Danube with Lake Cuhurlui, the Lapteș channel, derived from the Chilia branch of the Danube, close to the secondary delta, etc.
} 
Tsarist Empire after 1812 took over the local Romanian or Turkic hydronymy, their contribution to the diversification of the toponymic stock being reduced or artificially imposed by means of official measures.

Beyond these regional differences, if we analyse the distribution of the origin of hydronyms by large landform units (mountains, plateaus and plains), we find a predominant extension of certain categories. Hydronyms of Turkic origin are present (with small exceptions) predominantly in plain or low hill areas, being closely related to accessibility, an essential element for the nomadic populations, for this reason extending to the main Carpathian passages (e.g., Oituz, Uz). Hydronyms of Hungarian origin are present almost exclusively in the mountainous and sub-mountainous area, representing an extension of the toponymic system in Szeklerland, their presence being also closely related to the Carpathian passages. Hydronyms of Slavic origin are more frequent in the plateau areas, especially in their higher area (Hotin Plateau, Suceava Plateau, Central Moldavian Plateau). Plain areas seem to paradoxically have a higher share of Romanian hydronyms (including those derived from linguistic loans), which can also be attributed to a late (re) settlement. From the perspective of the size of the watercourses there is an inversely proportional relationship between their length and the share of Romanian hydronyms. There is a clear-cut distinction between water courses less than $25 \mathrm{~km}$ long and those above this length $(79.3 \%$ Romanian hydronyms, of which $32.8 \%$ are derived from Latin words, as compared to only $47.9 \%$ in the case of watercourses between $25-100 \mathrm{~km}$ and $10.2 \%$ for those over $100 \mathrm{~km}$ ). The largest share of the hydronyms of Slavic origin is recorded for medium water courses, between $25-50 \mathrm{~km}$, while hydronyms of Turkic origin occur mainly in the case of rivers with a length of more than $50 \mathrm{~km}$.

\subsection{Distribution and typology of hydronyms by significance}

For the primary processing of the information on the significance of hydronyms, 9 categories were separated: a) hydronyms that express the morphology of water courses and valleys, or that reflect the characteristics of the local relief (MORF); b) hydronyms inspired by the characteristics of the local geological substrate (LIT); c) descriptive hydronyms, suggesting water / valley features (DESC); d) hydronyms invoking faunistic (ZOO) or floristic (FIT) elements; e) hydronyms that are related to certain economic activities (ECON); f) hydronyms bearing personal names (ANT); g) hydronyms that originate in or derive from the name of villages $(\mathrm{OICO})^{13} ; \mathrm{h}$ ) hydronyms formed by diminutivation or derivation (DER).

a. The first category (MORF) has an important share (15\%), the most common meanings reflecting:

1) the isolated position, at the sources, 44 cases, the most representative ones being derived from the themes fund- (Fundoaia, Fundătura, Fundul, 12 cases) and gîrb- (Gîrbova, Gîrbele, Gîrbosu), etc.;

2) the size of the valley, the most frequent being the width (Larga, Largul, Valea Mare, 43 cases) or the length (Lunga, Valea Lungă, 18 cases);

3) fragmentation of the relief, especially in the hilly area ( 40 cases with a high frequency of the name Valea Rea - 15 situations, Găunoasa, Găureana, Ponoru, Ruptura, Hîrtopu);

4) the depth of fragmentation of the relief, 20 cases, the most frequently used being the Romanian word adînc- (often in the form Valea Adîncă) and the East Slavic hlybok-, with different phonetic adaptations (Hlibocioc, Hlibicioc, Hulbucioc, etc.);

5) the sinuousness of the course or valley, 20 illustrative cases being those derived from the Slavic theme kriv - (Crivăț, Crivec), but also Colacul, Strîmba, Codreava, Pîrîul Întors, Belciugul or derived from the Turkic çukur, etc.;

6) the flatness of the landform, 24 cases, frequently using the terms șes, podiş but also neted (Valea Netedă, affluent of Cerlina in the middle basin of Prut, etc.);

7) the accessibility of the valley, expressed by hydronyms such as Putna, Putila, Brodina, Telejna, derived from Slavic words (put', brod, teléga), 15 cases in total;

\footnotetext{
${ }^{13}$ In this situation, the age of the oikonyms was taken into account, since there is a possibility for villages to take over the names of the valleys in which they are built.
} 
8) the overflow of the major bed, most frequently expressed by the theme bahnă (8 cases, including derivates), and șar (Șărișor, Șaroș), lapoș, volo(a)că, etc. They are specific to the western part of Moldavia;

b. The characteristics of the lithology (LIT) are less represented, in line with the landform developed mostly on loose soft rocks, which do not stand out through spectacular forms except for the mountain area and the middle Nistru valley. Representing only $3.2 \%$ of the total, these hydronyms have a higher frequency in the mentioned areas where the Carpathian orogenic rock or the old rocks from the East European Platform appear on the surface. The most common are based on Romanian piatră, a term with imprecise significance, which, however, refers to the hardness of the rock. Of the 41 hydronyms with this base, most are Pietrosu (Chetrosu), but hydronyms such as Cremenea, Stinca, or those developed from kamen (Slavic), taş (Turkic) or köves (Hungarian) roots are not rare either ${ }^{14}$. Significant is also the frequency of hydronyms that remind of the brittle character of substrate rocks, 19 in number (mostly developed from the glod theme but also bumă, nisip, the Slavic theme $g(h)$ lin or the unsure theme $\operatorname{mol}(n)$.

c. Descriptive hydronyms (DESC) have a high frequency (16.5\%), the names of watercourses derived from physico-chemical characteristics being frequently used all over the world:

1) chromatic descriptors have a very high frequency, especially negru ('black', 27 cases), alb ('white', 25 cases) and roșu ('red', 22 cases, including ruginos 'rust'), generally reflecting the presence of some suspended materials or the color of the gravel. Widespread, these hydronyms were formed mainly by starting from Romanian words, associating terms such as izvor 'spring', pirîu 'stream' or vale 'valley'. However, especially for the white and black meanings, there is a significant presence of the Slavic roots bel and $\check{c} r n \check{\imath}$ (Bila, Bilca, Bilahoi or Ciorna, Cernița, etc.), more frequently in the northern half of the region. The yellow color was attributed exclusively to watercourses in low hilly regions in the south-east of the region ( 5 cases, including the use of the Turkic sart).

2) taste descriptors, reflecting the chemical composition of the water, are as frequent. Most hydronyms describe the salinity of the water (41 cases), with a higher frequency in the sub-Carpathian region, but also in hilly planes. Two thirds of them are based on the Romanian adjective sărat 'salty', with various associations, but also on the Slavic roots sol'- (Soloneț, Solca, etc.), especially in Bukovina and northern Bessarabia, or slatina, slanŭ, exclusively in the sub-Carpathian region ${ }^{15}$. In the southeast, Turkish themes also appear (Alcalia, for example). Much rarer are epithets that send to other chemical properties (sweet, bitter, sour).

3) descriptors illustrating the solid leakage (tulbure 'cloudy'/limpede 'clear') are not common, having a different distribution: in the plateau area for turbidity characteristics and in the sub-mountain area for water clarity.

4) thermal descriptors have a relatively low frequency, significant being the hydronyms developed from the Romanian adjective rece 'cold', with various variants (17, only one of which of Slavic origin: Studineț, in the Bîrlad basin). The absence of thermal waters on the territory of Moldavia can explain the rarity of hydronyms that refer to the higher temperature of water, frequent in other regions of the country, especially on the basis of the Slavic root topl $l^{16}$.

5) descriptors that relate to the drainage speed of the water, according to the predominance of the hilly landforms in which it is usually medium, are rarely encountered. Those that describe a high drain speed are present almost exclusively in the mountain area (formed both from the Romanian

\footnotetext{
${ }^{14}$ For example: Camenca, tributary of Răut or Prut, Camînca, tributary of Trotuş; Taşlîc, tributary of the Aliaga River, which flows into Lake Chitai, Tașbunar, tributary of Lake Cătlăbuga; Cuiejdiu, tributary of Bistrița, etc.

${ }^{15}$ The interference between the Slavic sol' (specific to the Eastern Slavic) and slanü (specific to the Southern Slavic) appears to occur in the Trotuș Basin, where we meet both Slănic and Solonț (a tributary of Tazlău). The latter is explained by a Hungarian intermediary but also corresponds to hydronyms in northeastern Ukraine (the basins of Desna and Don).

${ }^{16}$ The only exceptions are: Toplița, also called Horodnic, in the Suceava basin and Toplişoara, in the Neagra Broştenilor basin, in the vicinity of the Toplița tributary of the Upper Mureș, in the neogene volcanic area.
} 
adjective repede 'quickly' and from the Slavic roots bistr-, birz-), while those that describe a slow, quiet course are present in the plains. Much more frequent are the hydronyms that indicate an intermittent flow of water, including in the mountain area, as an expression of the continental climate specific to the region. There have been identified 47 hydronyms that integrate in various forms the Romanian adjective sec 'dry' (Secu, Seaca/Saca, Valea Seacă, etc.). In the northwest of the region there are a few hydronyms formed from the Eastern Slavic root sub- (Suha, Suhîi Potoc), and in the southwest we can mention Sușița, formed from a South Slavic root. In Budjak, hydronyms formed from the Turkic theme kuru (Curudere, Curugica) appear with the same meaning.

6) olfactory descriptors are another category, the most common hydronyms being developed from the Romanian adjectives putred 'rotten', puturos 'fetid', impuțit 'stinky', or pointing to the green colour, including by means of roots of Slavic (Hnila, Zelena, Dofteana, Dîhtineț) or Turkic (Marazli) origin. In some cases, they speak about the dirty appearance of water (Cacaina, Cacăț), generated by solid leakage. Generally, these hydronyms are rare in the mountain area and have a higher frequency in the hillside regions.

7) hydronyms that express positive impressions have a significant frequency, being related not necessarily to the water flow but rather to the aspect of the valley (frumos 'beautiful' - 14 cases, almost entirely of Romanian origin, bun 'good', drag 'dear', iubit 'beloved', bogat 'rich', etc.), spread at the level of the whole region. In this case, confusion may occur since many of these names may be of anthroponymic origin.

8) more difficult to define are the hydronyms that send to acoustic impressions, often related to the speed of drainage, many times derived from onomatopœias (Durduc, Duruitoarea) or using suggestive terms (Audia, Hangu, Turlui ${ }^{17}$ ).

d. There is also a wide dispersion of hydronyms that were named after the phyto-faunistic elements specific to the area (ZOO and FIT). In this case, just like in some of the ones mentioned above, it is difficult to accurately determine the origin of the name; they may be actually anthroponyms based on names of animals or plants. Their joint share is of $19.7 \%$ (out of which $8.8 \%$ are zoonyms). In terms of distribution, a higher frequency of phytonyms can be noticed in plain areas and in the main valleys, while zoonyms are more common in the mountain and hill areas. Most phytonyms derive from names of shrubs ( 58 cases), trees (50 cases), herbaceous plants (39 cases) or meadow vegetation (33 cases). More rarely, some phytonyms are the expression of hygrophilous associations (rogoz, stuf, trestie, typical of marsh vegetation) or agricultural activities (crop plants or fruit trees) ${ }^{18}$.

Of the shrub formations, significant for the formation of hydronyms are themes such as soc 'elder', corn 'cornel', singer 'dogwood' and alun 'hazel'. Also frequent are the hydronyms derived from collective nouns such as tufari, spini 'bush', or with the Slavic root trünü (Tîrnauca, Tîrnova).

As for the forest ecosystems, they generally comply with the vegetation floor. Thus, in the mountainous area are more frequent hydronyms that invoke the presence of fir, birch or beech (Rom. brad, mesteacăn, fag), in the hill area, oak, silver lime or hornbeam (Rom. stejar, tei, carpen), while the elm, maple and ash (Rom. ulm, paltin, frasin) have a more dispersed distribution. There are also exceptions, such as the Valea Bradului in the Nistru Plateau (Ocniţa district, Moldova). Phytonyms of Slavic origin (dub, buk, berest, lipa) are especially present in the northwest of the region, but they are also found in the south (Lipovăț, Lipova, etc.).

Of the herbaceous plants, brustur 'burdocks' has a significant frequency, especially in the mountain

\footnotetext{
${ }^{17}$ We refer to the possibility of deriving the Hangu name from the Hungarian hang 'sound', and the possibility of a Romanian translation (or vice versa) in the case of Audia. As for Turlui, which at first sight seems to be Turkic, we also took into account the possible derivation from the Romanian verb a turlui.

${ }^{18}$ It is worth mentioning hydronyms that indicate the presence of plants rarely cultivated nowadays (Pasat/Mălai/Parincea) or of some regionalisms (curechi 'cabbage'), especially in the plain area. Of the fruit trees, the apple, the cherry and the plum occur most frequently, especially in the mountain and hill areas.
} 
area, while bujor 'peony', boz 'dwarf elder' and pelin 'absinthe' occur often in the hilly and plain areas. As regards the meadow vegetation, very prolific are the hydronyms indicating the presence of the willow, both with Romanian suffixes (Răchitiș, Răchitoasa) and with Slavic ones (Răchitna or, Hungarian mediated, Răcătău). Hydronyms indicating the presence of poplar (plopin Romanian) are quite frequent, including Slavic forms such as Topolița or Topolovăț. Most hydronyms that indicate the meadow vegetation are located in the hilly areas, without being absent in the rest of the region.

The most common zoonyms are based on names of mammals (115 cases), the most common being the presence of the wolf, especially in Romanian form (lup, with many derivates), but also Slavic (vilk/vulk/volk) or Hungarian (farkas), present everywhere and with a paradoxically high frequency in the low hill or plain areas. Equally frequent are the hydronyms that invoke the presence of big herbivores such as the auroch and the bull (bour, taur, zimbru), predominantly in the mountain and the plateau areas. Quite often, there are hydronyms that indicate the presence of the wild boar (porc mistreț) or the bear (urs), also in the plateau area. At least in the last case, we can presume its derivation from the anthroponym Ursu, being difficult to accept the presence of this mammal in the steppic area (Ursoaia, a tributary of Botna, in the lower basin of Nistru or Medveja, a tributary of Prut at Lipcani, for example). The possibilities of explaining the series La Ursoi, Ursoiul, Ursoaia are much more varied, according to their multiple meanings (Ciubotaru, 2007). The roebuck (căprior, including Slavic form, koza) often appears in hydronyms in the mountainous area, and rarely in the lowlands (Căprioara, a tributary of Ceaga, in the Cogîlnic basin, Budjak). Significant are also the hydronyms indicating the presence of lost mammals: wild donkey (colun; Colonița, tributaries of Cubolta or Bîc, situated in steppe regions), elk (plotun; Platonița ${ }^{19}$, a tributary of the Șomuzul Mare, Plotunul, a tributary of Ozana) or the already mentioned case of auroch, especially in the mountain and piedmont areas. There are also hydronyms that derive from smaller animals such as the badger, the linx, the fox (bursuc/viezure, rîs, vulpe) or even the mouse (soarece). Some hydronyms are also based on the names of some domestic animals, especially the horse (Romanian cal or Slavic kobyla), sheep, cow, often related to pastoral activities, usually in the lowlands.

The poultry fauna generated less hydronyms ( 42 cases) with a remarkable frequency of several species: the raven (Romanian or Est-Salvic voron), the falcon (Romanian șoim or the Turkic balaban, especially in the plain area), the crow (cioara) and wild hen (only in the mountain area). Of the invertebrates, the frequency of hydronyms formed from the name of the crayfish (rac; Racova, Racovăț) is significant, especially in the plateau area.

e. Economic activities (ECON) have imposed the name of $10 \%$ of the inventoried hydronyms. Although less frequent, their presence is ubiquitous.

Most of them reflect deforestation and clearing activities (33 cases), located predominantly in the mountainous and hilly area, with a high frequency of terms indicating ways of removing natural vegetation (burning, cutting, draining, etc.). Very often, terms such as poiană, runc, arșiţă, tăietură, secătură, ciungi, prisacă, etc. are integrated in hydronyms. In strong relation to these, there are the activities of exploiting the forest resources (tocilă, banc, etc.) or which indicate the isolated habitation of forest areas $(b u d \breve{a}$ ), in a total of 24 other cases. Hydronyms imposed by land planning (incorporating terms such as hotar, branişte, hat, șanț, etc.) or indicating membership to a rural community (Valea Satului, 8 cases, Valea Caselor, 4 cases, etc.) are just as frequent. A second category is represented by hydronyms that reflect agricultural practices, with the frequent integration of some words like siliste or cimp (associated especially with vale). There are other terms in the mountain area such as hold or derived from the Slavic sad.

Water use is another economic activity frequently invoked by some hydronyms, whether it is about milling ( 7 cases), fishing activities (iaz, iezer), processing of textile raw materials (topilă/ tochilă, villtoare, chiuă) or of consumption goods, especially in semi-arid conditions (cişmea, cainar, terms of Turkic

${ }^{19}$ Considered in MDTM (p. 324) as being derived from a person's name. 
origin).

f. The derivation of hydronyms from anthroponyms (ANTR), which most often designate property, is the most frequent of the categories (19.4\%). Higher values are specific to the Jijia Basin or the Bugeac Plain, areas heavily affected by the (systematic) agricultural colonization in the $19^{\text {th }}$ century. The great variety of forms can be explained by the many possibilities of derivation, from the proper names (Dumitru, for example, the tributary of Tarcău), to diminutives (Dumitrița, tributary of Siretul Mic) or to suffixes that most often indicate ownership (Drăgoiasca, Negoștina, Mihova, Voievodeasa ${ }^{20}$, Brădeasa, Șerboaia, Buhușoaia, etc.). Very frequent are the hydronyms that bear names of people not used for a long time (Brateș, Trifon, Murgoci, Șandru, Giurgiu, etc.) while in the south-east there are predominantly hydronyms whose names derive from some Nogai leaders (Casim, Cantemir, Batîr, Bulat, etc.). Very frequent are also the hydronyms formed by associating the noun valea (Valea lui Constantin, in the basin of Ialpuh Lake, Valea Ungurului in the basin of Lake Cahul, or Valea Ilenei in the basin of Bahlui, for example). Some send to certain public dignities (Vămăşoaia, Pîrcălabul, etc.).

g. The derivation of hydronyms from oikonyms (OICO) is quite frequent (12.9\%), either by actually using the name of the locality (e.g., Grigorești, Sălăgeni, in the upper basin of the Siret), or by using suffixes such as -easca (Corceasca, Hănțeasca, within the same basin), -eanca (e.g., Gîrceanca, in the basin of Racova), or by association with the noun vale 'valley' (Valea Moișii, tributary of Rîșca or Valea Bălăbănești, tributary of Jeravăț, Valea Trușenilor in the basin of Bîcul, for example). There are also isolated cases of association with the noun matcă (Matca Stănileștilor, affluent of Cerlina at Mămăliga, Novoselița district, Chernivtsi region) or by adding to a hydronym the name of the village (Suha Stulpicanilor, in the basin of Moldova, Sovița Șipinților or Sovița Cozmenilor in the upper basin of the Prut, etc.). As a general rule, the oikonyme-derived hydronyms are more common in hilly and plain regions, especially in areas that have undergone massive rural colonization in the $19^{\text {th }}$ century (Middle Prut Plain, Budjak Plain, etc.).

h. The last category of hydronyms by significance, those derived (DER) by attributing a differentiating qualificative or diminutive is relatively rare (only $3 \%$ ). The most often usd adjectives are mare 'great' and mic 'small', and diminutives with the suffixes - oara, -ica, -ița, -uţa, -eț or -el: Siret - Siretul Mic - Sirețel; Putna - Putna Mică (Moldova basin), Brodina - Brodinioara or Putna - Putnișoara (Suceava basin), Sărata - Sărațica (lower Prut basin), Dorna - Dornişoara or Bistrița - Bistricioara (Bistrița basin), Milcov - Milcovel or Lepșa - Lepșuleț (Putna basin), Salcia Mare - Salcia Mică and Lunga - Lunguța (Ialpuh basin). In some cases, the derivatives are hierarchized by size or position (Ciulucul Mare, Ciulucul de Mijloc and Ciulucul Mic in the Răut basin, or Sovățul Mare, Sovățul Mic and Sovățul de Jos in the middle Prut basin). Of the 68 hydronyms in this category, most of them are in the Carpathian region and in the central-southern part of Bessarabia.

The typological classification according to the methodology already presented identified six distinct areas from the perspective of the combination of hydronyms by significance, partially overlapping those differentiated by origin. The contrast between the western part of the region (where all six types are present) and the eastern one (where only four of them occur) can be seen either as a reflection of the peculiarities of the natural environment, more complex in the west, or as a consequence of the late settlement, correlated with the preponderance of hydronyms derived from anthroponyms and oikonyms in the east.

The first two types are clearly distinguishable by the predominance of hydronyms based on elements of the natural environment, being located mostly in the western part of the region. The difference between them lies in in the greater importance of hydronyms expressing morpho-lithological features for type 1 and a relatively higher importance of descriptive hydronyms or phytonyms in the case of type 2 . The latter is at the limit of being considered a Carpathian type. The juxtaposition of the Botna basin, the upper part

\footnotetext{
${ }^{20}$ Considered to be the Romanian translation of the German Fürstenthal (Prisacaru, 2013), although it appears at Gonța with the mention "the creek at Sucevița, XVI-III, 226” (GONŢA, p. 280).
} 


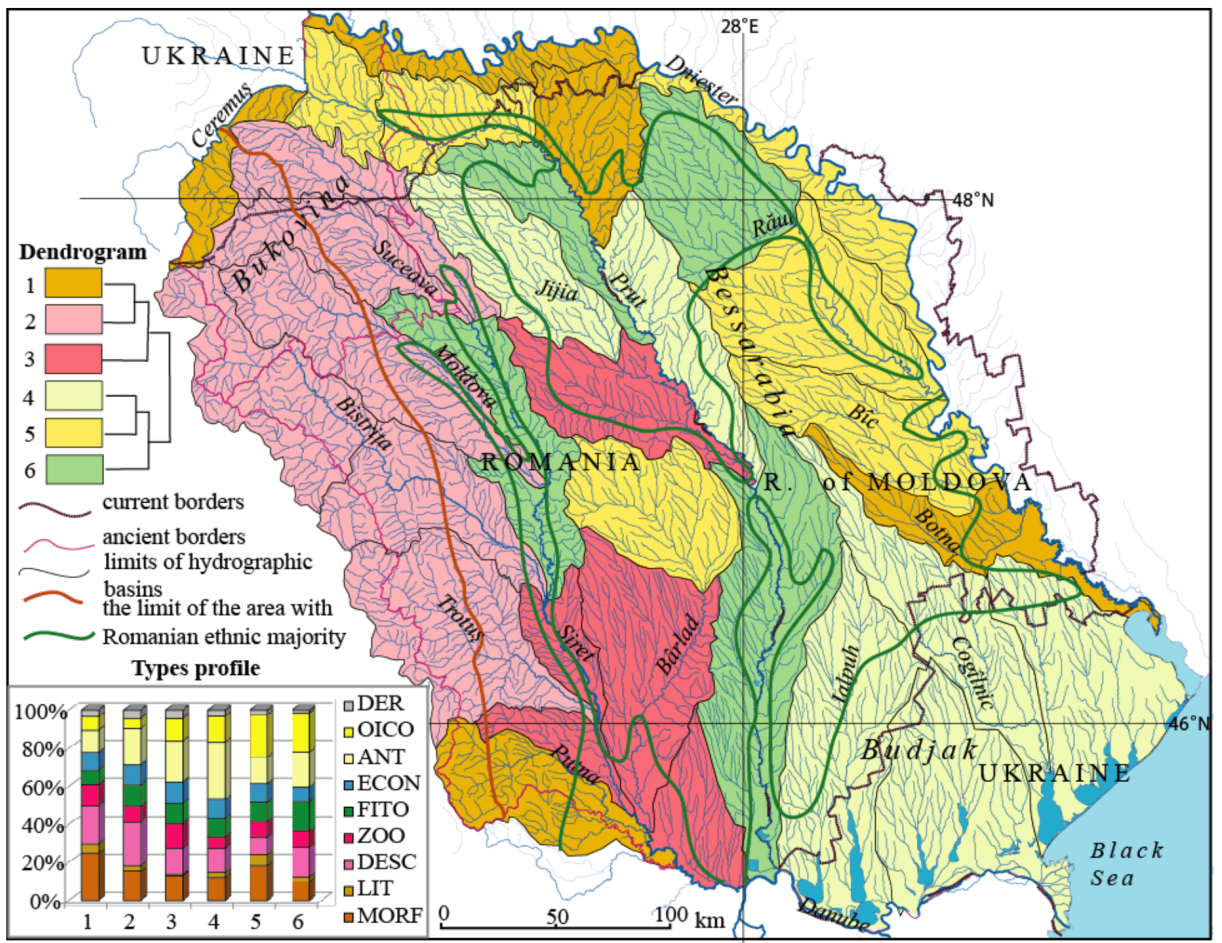

Figure 2: Typology of hydronyms in Moldavia by significance

of the Dniester Valley (in its Moldavian sector) and the northern part of the middle Prut basin (Vilia Racovăț - Ciuhur) may seem eccentric, but it can be explained through the higher frequency of morphoand lithonymes (Fig. 2). Type 3 is a variation of the first two, differentiated by the slightly higher share of hydronyms derived from anthroponomyms and oikonyms. Located exclusively in the western part of the region (the basins of Suceava, Bahlui and Bîrlad), it is the closest to the region's average profile, with the highest share of zoonyms.

The last three types are distinguished by the superior net share of anthroponyms and oikonyms, respectively a weaker representation of descriptive hydronyms. Type 4 is characterized by the very large share of anthroponyms (over 30\%) being typical of Budjak and of significant parts of the middle Prut basin, areas with a massive agricultural colonization in the $19^{\text {th }}$ century. Type 5 reveals a large share of oikonyms in the formation of hydronyms, a situation specific to some plateau areas (the upper basin of Bîrlad, the lower basin of Răut, the basin of Bîc, the upper basin of Prut, etc.). Another difference is the high share of hydronyms expressing geomorphological particularities, a situation that can be explained in the context of fragmentation of the relief in the above-mentioned regions. Type 6, typical of the Lower Prut Valley, the Steppe of Bălți, the Bașeu basin and the Middle Siret valley, has a significantly greater share of phytonyms and descriptive hydronyms, although the latter do not reach the values of types 1 or 2 .

The classification reveals, as in the case of the origin of hydronyms, an East-West difference closely related to morphological and bio-geographical characteristics. The differences between the six types can also be interpreted as a chronological stratification of hydronyms, older and more stable in the western part of the region, later and more unstable as we advance to the east and south-east of the region. This hypothesis is based on the assumption that many denominations of valleys or streams that derive from anthroponyms or oikonyms are recent, many of them being administratively assigned.

Moreover, analysed by large geographic units, the distribution of hydronym categories by significance reveals substantial differences between the mountain area and the low regions (hills and plains). In comparison with the slight predominance of hydronyms derived from elements of the natural environment at the regional level (54.3\%), the highest net values (62.9\%) are recorded in the mountain area. The mountainous area is also remarkable by the over-representation of descriptive hydronyms (23.4\%) and of 
those derived from economic activities (11.2\%). The variety of geographic landscape and the role of forest exploitation in the evolution of the settlement process can explain this situation. In contrast, hill areas are characterized by the over-representation of oikonymes and morphonymes (18 and 16.5\%, respectively), while plains stand out through the predominance of anthroponyms and phytonyms $(25.6 \%$ and $13.1 \%$, respectively). Descriptive hydronyms are generally less common in low regions. The frequency of the geomorphological processes and the low prominence of water courses (low flows, simple morphometry) are plausible explanations for the features of the hilly area. In plain areas, the preference for the abovementioned hydronym types is correlated with the importance of the valley land planing and with the various types of vegetation, in opposition to the monotony of steppe spaces.

\section{Conclusions}

The presented results confirm the importance of the geographic study of hydronyms, in line with the proposed objective: the analysis of the spatial distribution of hydronyms in correlation with their origin and significance from a natural or human-geographic perspective. The two classifications drawn up in accordance with the rules of descriptive statistics generate the existence of distinct areas, sufficiently differentiated by the frequency of certain categories of hydronyms, either in relation to their origin or to their significance.

It can be preliminarily stated that the gradual disposition of landforms from the Carpathians to the East induces a first division of the historical Moldavian space: the mountainous and sub mountainous areas stand out through the interpenetration of Slavic and Transylvanian influences, with a prevalence of the natural significance of the denominations of watercourses, while the steppe area of Budjak comes forward due to the persistence of Turkic influences, more diffuse in the rest, and to the great significance of meanings of anthropic origin. Between these two geographically distinct spaces, the rest of the territory, mostly overlapped on the Plateau of Moldavia, is characterized by the gradual north-south disposition of the Slavic influence and by a more complex profile of the meanings, closely related to the morpholithological and bio-geographic characteristics or to the evolution of the settlement system ${ }^{21}$. The personalization of the physico-geographic subunits of the Moldavian Plateau from this double perspective is unquestionable, the Plain of Jijia being sufficiently different from the Plateau of Bîrlad for example.

A second division is induced by the political factor, which, by dismantling this once unitary territory, forced the substantial change of toponymy as a whole, generating differences that seem to separate mainly Bessarabia from the western part of Moldavia, but also Bukovina, especially its northern part. Changing the name of some hydronyms, translating them or adapting them to the languages of the current majority populations is a direct consequence ${ }^{22}$. The way in which the hydronyms settled over time favoured, in most of Bessarabia, the process of derivation from anthroponyms and especially from oikonyms, many of which were probably imposed when modern cartographic measures appeared, when small valleys or streams had

\footnotetext{
${ }^{21}$ By the Moldavian Plateau we understand the entire physical-geographic unit developed on the East European geological basis, with a hilly fragmentation between the Obcine of Bukovina and Subcarpathians in the west, the Romanian Plain in the southwest and the Dniester. It comprises $3 / 4$ of the territory of historical Moldova and it is defining for it from a geographical point of view.

${ }^{22}$ It is a more frequent situation in Bukovina, where many hydronyms that appear with Romanian forms in older cartographic dictionaries or documents have been modified so that they can hardly be recognized: Porcul, a tributary of Putila, today Porkulin; Izvoraș, a tributary of the upper Siret, today Zvaraș (Zvarici), downstream, another tributary of the same river, Siliștea, being today transcribed as Selici; Vîltori, in the basin of Hlinița, right tributary of Prut, today Vivtar; Pisareul, in the basin of Hlibocioc, right tributary of Prut, today, Psiarev, etc. In Hotin county there are also such examples: Hîrtopul, a tributary of Chetroasa, nowadays Krokva, or Surda (as it appears in ARBORE, who says that the Russian name is Surta), nowadays Surșa, possibly by contamination with the name of a left tributary of the Dniester, Surja whose confluence is nearby. It can be assumed that many of the minor hydronyms in the northwest of historical Moldavia, which today are of Ukrainian origin, have disappeared, not being recorded, the current ones being recent. In the same sense, however, we can assume that in the rest of the territory original Slavic or Turanian names of many hydronyms were changed, being replaced by Romanian names.
} 
to be named, being previously undocumented during the Russian occupation. Such evolutions can also be invoked in the rest of the territory in similar contexts.

\section{Bibliography}

\section{A. References}

Brezianu, S. (2002). Identități și solidarități medievale, Corint, București.

Butnaru, D. (2011). Toponimia bazinului hidrografic al Neamțtului, Alfa, Iași.

Ciubotaru, M. (2001). Oronimia şi bidronimia din bazinul superior al Bârladului, Demiurg, Iași.

Ciubotaru, M. (2007). Toponimie și zoonimie. Observații metodologiceși distincții etimologice, in "Anuar de Lingvistică și Istorie Literară", tom. XLVII-XLVIII, A, p. 101-111.

Cojocaru, V. (2005). Toponimia văii mijlocii a Trotuşului. Dinamica structurilor toponimice, Demiurg, Iași.

Eremia, A. (2012). Hidronimia bazinului bidrografic al Dunării, in "Buletin de Lingvistică", 13, p. 66-74.

Eremia, A. (2014). Originea toponimelor, controverse de opinii, etimologii false, in "Philologia", LVI, p. 62-72.

Eremia, A. (2017). Hidronimia bazinului bidrografic al Nistrului, in "Akademos", 3, p. 132-138.

Felecan, O. \& Felecan, N. (2015). Straturi toponimice reflectate în hidronimia românească, in "Quaderns de Filologia: Estudis Lingüístics", XX, p. 251-269, Crossref.

Hastie, T. et al. (2009). Hierarchical clustering, în The Elements of Statistical Learning, Springer, New York.

Krahe, H. (1964). Unsere ältesten Flussnamen, Harrasowitz, Wiesbaden.

Lebel, P. (1956). Principes et méthodes d'hydronymie française, Les Belles Lettres, Paris.

Moldovanu, D. (1987). Hidronime românești de origine slavă: Bîrladul, Ialomița, Jijia, în „Anuar de lingvistică și istorie literară”, XXXI, 1986-1987, A, p. 291-312.

Moldovanu, D. (2007-2008). Hidronime de origine veche turcică în sudul Moldovei, in "Anuar de lingvistică și istorie literară", XLVII-XLVIII, p. 9-28.

Peust, C. (2015). How old are the River Names of Europe? A Glottochronological Approach, in "Linguistik Online", 70 (1), p. 185-218, Crossref.

Prisacaru, A.-M. (2013). Reromânizare toponimică. Cu aplicații la toponimia românească din Bucovina habsburgică (actualele teritorii românești), in Cultură și identitate românească. Tendințe acutale și reflectarea lor in diaspora, Editura Universității „Alexandru Ioan Cuza”, Iași.

Raevschi, N. (2006). Hidronime traco-dace având conexiuni etimologice baltice, in "Limba Română", XVI (7-9), p. 93-111.

Spinei, V. (1999). Marile migrații din estul și sud-estul Europei in secolele IX-XIII, Institutul European, Iaşi.

Ungureanu, A. \& Boamfă, I. (2006). Toponomastică, Sedcom Libris, Iaşi.

Urazmetova A.V. \& Șamsutdinova, J.K. (2017). Principles of place namesclassifications, in “Xlingux", 10 (4), p. 26-33, Crossref. Vennemann, T. (2003). Europa Vasconica - Europa Semitica, Walter de Gruyter, Berlin.

Вербич, С. (2015). Слованско - східнороманска взаємодія гідронімї басейну Анистра: Оригінална назвита структурно адаптовани утворення [Slavic and Eastern Romance interaction in the hydronymy of the Dniester river basin], in ,Linguistica", 55 (1), p. 115-129, Crossref.

Топоров, В.Н. \& Трубачев, О.Н. (1962). Аингвистический анализ гидронимов Верхнево Поднепровья, Академий Наук СССР, Москва.

\section{B. Sources}

ARBORE = Arbore, Z. (2012). Dicționarul geografic al Basarabiei, Sæculum, București.

ATLAS MOLD. = Atlasul Moldovei (1:50 000), Institutul Geografic al Armatei, București, 1892-1898.

FNDG = Fondul național de date geospațiale, [online, consultat în perioada 2016-2018].

GONȚA = Gonța, Al. (1990). Documente privind Istoria României. A. Moldova. Veacurile XIV-XVII (1384-1625). Indicele numelor de locuri, Editura Academiei, București, 1990.

GRIGOROVITZA = Grigorovitza, E. (1908). Dicționarul geografic al Bucovinei, Tipografia I.G. Lahovari, București, 1908.

HARTA BUC. = Iosep, I. (coord.) (2014). Cele dintâi hărţi ale Bucovinei - Oretrospectivă necesarăa, Editura Romstorfer, Suceava. HARTA TOP. $=$ Harta topografică (1:50 000), Direcția topografică militară, [online, consultat în perioada 2015-2018].

HARTA URSS = Harta topografică militară a U.R.S.S. (1:100 000), foile Căușani, Sarata, Cetatea Albă, Tuzla, Tatarbunar, Arciz,

Chilia, Izmail, Bolgrad, Galați, Secureni, Chelmenți, Hotin, Novoselița, Cernăuți, Sneatin, Vijnița, Putila și Băile Borșa, [online, consultat în perioada 2008-2012].

HIDR. UCR. = Непокупний, А.П. et al. (1979). Словник гідронімів Украӥни, Наукова Аумка, Київ.

MDG = Lahovary, Al.G. (1898-1902). Marele Dicționar Geografic al României, I-V, Socec, București.

MDTM = Tezaurul toponimic al României. Moldova, II, Mic dicționar toponimic al Moldovei. Structural și etimologic, Partea 1.

Toponime personale (coord. D. Moldovanu), Editura Universității „Alexandru Ioan Cuza”, Iaşi, 2014.

TTRM = Tezaurul toponimic al României. Moldova (coord. D. Moldovanu). $\mathrm{I}_{1-2}$, Repertoriul istoric al unităților administrativteritoriale (1772-1988), Editura Academiei, București, 1991-1992. 